\title{
Introduction To "'Daddy Lives at the Airport': The Consequences of Economically Driven Separation on Family Life in the Post-Industrial Mining Communities of Cape Breton"
}

\author{
Victor G. Devinatz
}

Published online: 22 April 2012

(C) Springer Science+Business Media, LLC 2012

As unemployment remains stubbornly high in many nations throughout the world in 2012, more and more workers might consider and subsequently seek employment arrangements under less than desirable conditions in order to continue to support themselves and their families. Some of these unattractive employment situations might include jobs in which the employees are separated from their families for extended periods of time. For example, certain occupations such as deep-sea fishing, the merchant marine, the military, and the offshore oil industry all, because of the very nature of the work, unfortunately require that the workers endure long separations from their families.

In this well-written and timely "Perspectives" Section article, David Wray, Senior Lecturer in the Division of Social Sciences at the University of Northumbria (United Kingdom), examines how migratory work negatively impacts family life. In particular, Mr. Wray explores migrant workers from the post-industrial mining communities of Cape Breton Island (Canada) by investigating the stressors of economically driven separation on various kinds of family structures. Additionally, the author proffers a number of alternative remedial strategies that might lessen the destructive effects of migration on family life.

Mr. Wray, who has written widely and insightfully on various aspects of the coal mining industry and mining communities, often, brings an insider's perspective to his scholarly work. Upon leaving school at 16 years of age, Mr. Wray commenced work in coalmining as an apprentice electrician. After spending nearly a quarter of a century employed at various collieries in the Durham Coalfield, he lost his position following the conclusion of the National Union of Mineworkers' historic strike of 1984-85.

If any of the journal's readers would like to respond to essays published in the "Perspectives" Section or would like to write on any topics in the field of employee relations, please do not hesitate to contact me with your proposal. I welcome both practitioner-based and scholarly-based articles written from any one of a variety of theoretical perspectives. I hope that you enjoy this article and find it most illuminating.

\footnotetext{
V. G. Devinatz $(\bowtie)$

Department of Management \& Quantitative Methods, Illinois State University, Normal, IL 61790-5580, USA

e-mail: vgdevin@ilstu.edu
} 